\title{
A STUDY ON BIRTHWEIGHT AND INTELLIGENCE
}

\author{
BंY \\ CÉCILE ASHER* and J. A. FRASER ROBERTS \\ From the Institute of Child Health, University of London, and the Burden Mental Research Department, \\ Stoke Park Colony, Bristol
}

\section{INTRODUCTION}

The mental development of the premature or immature child has been studied by a number of investigators. The literature has been summarized recently by one of us (Asher, 1946). But although there is a considerable body of information on the subsequent intelligence of children of low birthweight, so far as we are aware no study has been carried out on the general relation of birthweight to intelligence in the population as a whole. Doubtless this is due to the formidable difficulty of following up after a sufficient number of years groups of children whose weights were accurately measured at birth. But is there no other approach ? It is a matter of common experience that most mothers do in fact remember the birthweights of their children, often being able to quote them to the nearest ounce after the lapse of many years. The $a$ priori objections to using this information are obvious enough. The mother of several children may get their birthweights mixed up. The weight as given to her may have been inaccurately determined. A proportion of mothers will have forgotten and the distribution of forgotten birthweights may not be the same as those that are remembered; there might well be a tendency, for example, for unusually high or low weights to be remembered more frequently than the rest. Nevertheless, it seems possible that for the comparison of the means of relatively large groups, weights as recollected by the mothers might be usable, for it is to be expected that errors of most types will be more or less randomly distributed. Accordingly it was decided to obtain from mothers the birthweights of a sample of children of school age. The distributions so obtained could then be compared with the distributions obtained from accurate hospital studies. Should this comparison prove satisfactory, the relation of birthweight to intelligence could then be examined, to a first approximation, by comparing the distributions of birthweights of children at

* Medical Officer, Ministry of Education schools and institutions of various types and $\vec{\sigma}$ containing children of very different mean intel- $\bar{\phi}$ ligence.

It may be helpful to summarize here the results of $\omega$ our investigation. The frequency distributions of a sample of birthweights as recollected by the mothers $\circ$ correspond closely with those of an accurately measured hospital sample; there is no difference between schools of different type, containing? children of very different mean intelligence; children $=$ at special schools for the educationally subnormal $\overrightarrow{0}$ and certified mental defectives differ from the rest $\overrightarrow{0}$ in showing a large excess of low birthweights and $\mathrm{a}-$ small excess of very high birthweights, but there is no shifting of the frequency curve as a whole.

\section{The Composttion of the SAmples}

For the benefit of those who may not be familiar with the present English school system it should be explained that children first attend a primary school. Apart from the mentally defective and very backward, the primary schools contain children of all $\$$ levels of intelligence. At the age of about $11+$ the children proceed to a secondary school; the clever-? est, as judged by a scholarship examination, or a 3 group intelligence scale, or more usually both, pass on to a secondary grammar school, the remainder to a secondary modern school. From the point of view of intelligence the distinction is a sharp one. The mean Binet I.Q. of secondary grammar school $\frac{}{2}$ children is about 120 ; that of secondary modern school children is about 95 .

Children who are ascertained under the Education Act (1944) as being educationally subnormal and $\mathrm{N}$ requiring special educational treatment may be admitted, at any stage of their school career, to special schools for the educationally subnormal. $\stackrel{0}{E}$ For brevity the term "special school" is used throughout this paper, and it will be understood. that it is solely this kind of special school that is $\frac{0}{0}$ meant and not any of the other types provided for $\overrightarrow{\mathbb{D}}$ children handicapped in other ways. The propor- $\frac{?}{\bar{D}}$ tion of children attending these special schools is 0 
relatively small. Furthermore, the proportion differs considerably in different areas, for there is legitimate diversity of opinion as to the best way of catering for backward children. For example, in some areas many are accommodated in special classes at the ordinary schools. In the County of Middlesex the percentage of children (ages 5-16) at special schools is at present 0.38 ; in the London County Council area it is 0.73 . The great majority of these children have Binet I.Q.s ranging from 50-75, rather less than 10 per cent. having I.Q.s outside this range. Selection is not made, however, solely on the basis of I.Q., though, of course, when a child has been submitted for examination on account of backwardness the I.Q. level is naturally an important factor in determining disposal.

The sample of children attending the ordinary schools was obtained from the Borough of Finchley, Middlesex. It should be mentioned that whereas the primary and secondary modern schools situated in the borough cater for Finchley children, there is a good deal of overlapping in regard to secondary grammar schools. In particular, the large boys' school shown in Table IV includes many pupils from outside the area; this explains the excess of boys in this portion of the sample.

There are four special schools in Middlesex and these formed the original special school sample. It was later decided to enlarge this important part of the material, so birthweights were obtained from seven additional special schools, situated in the London County Council area.

The sample of birthweights of certified mental defectives was obtained from Stoke Park Colony, Stapleton, Bristol.

\section{ASCERTAINMENT OF THE BIRTHWEIGHTS}

Through the schools slips were distributed to the mothers of the children asking them to fill in the birthweight. Rather more than 80 per cent. of the slips were duly completed, the main reason for omission being, of course, that the mother had forgotten. The birthweights of the mental defectives were ascertained (with the help of the local health authorities) in the same way.

It was thought best simply to ask for the birthweight, without specifying how this should be stated: for example, in pounds and ounces, or to the nearest quarter-pound. This has naturally produced a rounding off of the figures, as is shown by the distribution of the first 5,177 birthweights (the whole sample, less the extra special schools and the mental defectives). The observed frequencies compared with those expected had measurements been made to the nearest ounce are shown in Table I.

\begin{tabular}{|c|c|c|}
\hline \multirow{3}{*}{$\begin{array}{l}\text { ROUNDING-OFF OF } \\
\end{array}$} & IGHTS (FIRST & \multirow[t]{2}{*}{ ( 5,177) } \\
\hline & Frequencies & \\
\hline & $\begin{array}{c}\text { As Given by } \\
\text { Mother }\end{array}$ & $\begin{array}{c}\text { Expected } \\
\text { (Weights } \\
\text { taken to } \\
\text { nearest oz.) }\end{array}$ \\
\hline $\begin{array}{l}\text { To whole pound } . . \\
\text { To half-pound } \ldots \\
\text { To quarter-pound } \\
\text { To three-quarter pound } \\
\text { To intermediate ounces }\end{array}$ & $\begin{array}{r}1,375 \\
1,399 \\
583 \\
589 \\
1,231\end{array}$ & $\begin{array}{r}323 \cdot 6 \\
323 \cdot 6 \\
323 \cdot 6 \\
323 \cdot 6 \\
3,882 \cdot 7\end{array}$ \\
\hline Total .. & 5,177 & $5,177 \cdot 1$ \\
\hline
\end{tabular}

There was a strong tendency for weights to be given either to whole pounds or half-pounds, but fortunately none for whole pounds to be given more often than half-pounds; there was a slighter tendency to round off to the quarters and three-quarters. Thus the material can be grouped in one way only: namely, in half-pound groups with whole and half-pounds at the group centres. The quarter and three-quarter observations were distributed between the groups above and below in proportion to the numbers in those adjacent groups. The figures used for doing this were obtained from the whole original sample of 5,177; girls and boys were kept separate. The same figures were used for distributing the quarters and three-quarters amongst the additional special school sample and the mental defectives. The frequency distributions obtained are shown in Table II. The fractional frequencies are, of course, due to the distribution of the quarters and threequarters.

\section{Comparison OF THE BirthWEIGHTS WITH AN} Accurately Measured Sample

An excellent sample of birthweights with which to compare the present material is that of Martin (1931). His series was composed of live births at Queen Charlotte's Hospital, London, during the years 1922-25. Thus both samples consist of children drawn from Greater London; the numbers are fairly similar; twins are included in both. The one important difference is that Martin's sample included all live births, while ours represents survivors to various school ages. In our sample the special school and mentally defective children are heavily over-represented (this fraction of the child 
TABLE II

FrequenCy Distribution of BirthWEIGHTS*

\begin{tabular}{|c|c|c|c|c|c|c|c|c|}
\hline \multirow{2}{*}{$\begin{array}{c}\text { Group } \\
\text { Central } \\
\text { Weights } \\
\text { (lb.) }\end{array}$} & \multicolumn{4}{|c|}{ Ordinary Schools } & \multirow{2}{*}{$\begin{array}{l}\text { Special } \\
\text { Schools }\end{array}$} & \multicolumn{3}{|c|}{ Mental Defectives } \\
\hline & Primary & $\begin{array}{l}\text { Secondary } \\
\text { Grammar }\end{array}$ & $\begin{array}{l}\text { Secondary } \\
\text { Modern }\end{array}$ & Total & & $\begin{array}{l}\text { Feeble- } \\
\text { Minded }\end{array}$ & Imbeciles & Idiots \\
\hline $\begin{array}{r}1 \cdot 5 \\
2.0 \\
2.5 \\
3.0 \\
3.5 \\
4.0 \\
4.5 \\
5.0 \\
5.5 \\
6.0 \\
6.5 \\
7.0 \\
7.5 \\
8.0 \\
8.5 \\
9.0 \\
9.5 \\
10.0 \\
10.5 \\
11.0 \\
11.5 \\
12.0 \\
12.5\end{array}$ & $\begin{array}{r}-\overline{1.0} \\
1.0 \\
2.0 \\
5.4 \\
11.4 \\
21.7 \\
38.1 \\
46.2 \\
118.6 \\
162.8 \\
206.5 \\
200.4 \\
165.3 \\
128.4 \\
40.5 \\
24.9 \\
19.0 \\
3.8 \\
1.0 \\
1.0 \\
1.0 \\
-\end{array}$ & 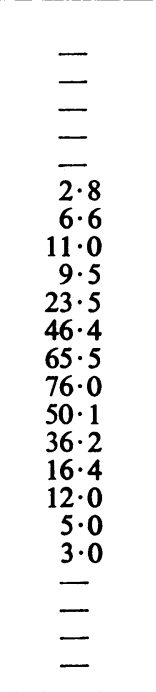 & $\begin{array}{r}\overline{7} \\
\overline{7} \\
7.7 \\
0.5 \\
10.2 \\
12.4 \\
10.3 \\
13.8 \\
22.7 \\
48.5 \\
79.5 \\
109.1 \\
118.6 \\
86.6 \\
68.1 \\
27.6 \\
15.8 \\
16.2 \\
0.4 \\
1.5 \\
1.5 \\
2.0 \\
1.0\end{array}$ & $\begin{array}{r}\text { Girls } \\
1.0 \\
8.7 \\
2.5 \\
15.6 \\
26.6 \\
38.6 \\
62.9 \\
78.4 \\
190.6 \\
288.7 \\
381 \cdot 1 \\
395.0 \\
302.0 \\
232.7 \\
84.5 \\
52.7 \\
40.2 \\
7.2 \\
2.5 \\
2.5 \\
3.0 \\
1.0\end{array}$ & $\begin{array}{r}\overline{2 \cdot 0} \\
3 \cdot 0 \\
6 \cdot 0 \\
6 \cdot 8 \\
6 \cdot 4 \\
10 \cdot 8 \\
18 \cdot 2 \\
19 \cdot 3 \\
39 \cdot 3 \\
46 \cdot 6 \\
58 \cdot 0 \\
57 \cdot 9 \\
30 \cdot 5 \\
30 \cdot 3 \\
17 \cdot 9 \\
10 \cdot 0 \\
5 \cdot 4 \\
1.6 \\
3 \cdot 0 \\
1 \cdot 0 \\
1.0\end{array}$ & $\begin{array}{l}\bar{Z} \\
1 \cdot 0 \\
\bar{Z} \\
\overline{1 \cdot 0} \\
\bar{Z} \\
\overline{1} \\
3 \cdot 0 \\
2 \cdot 0 \\
2 \cdot 0 \\
1 \cdot 0 \\
2 \cdot 0 \\
1 \cdot 0 \\
1 \cdot 0 \\
\bar{Z} \\
= \\
=\end{array}$ & $\begin{array}{l}1 \cdot 0 \\
= \\
2 \cdot 0 \\
1 \cdot 4 \\
2 \cdot 6 \\
1 \cdot 7 \\
4 \cdot 3 \\
3 \cdot 3 \\
2 \cdot 7 \\
2 \cdot 8 \\
1 \cdot 2 \\
4 \cdot 2 \\
5 \cdot 4 \\
3 \cdot 4 \\
1 \cdot 0 \\
2 \cdot 0 \\
1 \cdot 0 \\
= \\
= \\
=\end{array}$ & $\begin{array}{l}\bar{Z} \\
\bar{Z} \\
1 \cdot 0 \\
1 \cdot 0 \\
\overline{3} \cdot 4 \\
2.9 \\
3 \cdot 6 \\
5 \cdot 1 \\
7 \cdot 5 \\
5 \cdot 1 \\
5 \cdot 4 \\
2 \cdot 0 \\
2 \cdot 0 \\
= \\
\bar{Z} \\
0 \cdot 5 \\
0.5 \\
=\end{array}$ \\
\hline Total & $1200 \cdot 0$ & $364 \cdot 0$ & $654 \cdot 0$ & $2218 \cdot 0$ & $375 \cdot 0$ & $15 \cdot 0$ & $40 \cdot 0$ & $40 \cdot 0$ \\
\hline \multirow{2}{*}{$\begin{array}{c}\text { Group } \\
\text { Central } \\
\text { Weights } \\
\text { (lb.) }\end{array}$} & \multicolumn{4}{|c|}{ Ordinary Schools } & & \multicolumn{3}{|c|}{ Mental Defectives } \\
\hline & Primary & $\begin{array}{l}\text { Secondary } \\
\text { Grammar }\end{array}$ & $\begin{array}{l}\text { Secondary } \\
\text { Modern }\end{array}$ & Total & $\mathbf{S}$ & $\begin{array}{l}\text { Feeble- } \\
\text { Minded }\end{array}$ & Imbeciles & Idiots \\
\hline 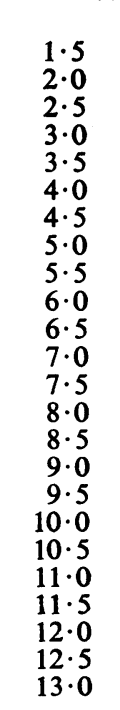 & 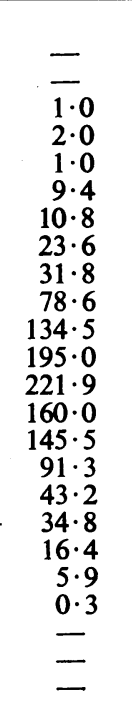 & $\begin{array}{c}\bar{Z} \\
\overline{-} \\
1 \cdot 0 \\
4.0 \\
0.3 \\
3.7 \\
18 \cdot 3 \\
20 \cdot 2 \\
32 \cdot 5 \\
70 \cdot 8 \\
86.7 \\
138 \cdot 7 \\
102.6 \\
70.2 \\
54.5 \\
27.7 \\
23.4 \\
4.4 \\
1.0 \\
1.6 \\
0.4 \\
= \\
-\end{array}$ & 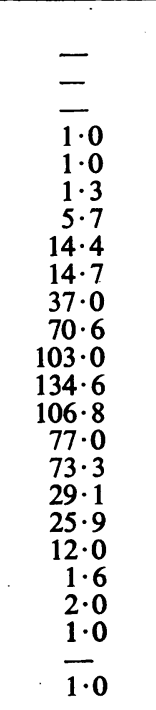 & $\begin{array}{r}\text { Boys } \\
= \\
1 \cdot 0 \\
4 \cdot 0 \\
6 \cdot 0 \\
11 \cdot 0 \\
20 \cdot 2 \\
56 \cdot 3 \\
66 \cdot 7 \\
148 \cdot 1 \\
275 \cdot 9 \\
384 \cdot 7 \\
495 \cdot 2 \\
369 \cdot 4 \\
292 \cdot 7 \\
219 \cdot 1 \\
100 \cdot 0 \\
84 \cdot 1 \\
32 \cdot 8 \\
8 \cdot 5 \\
3 \cdot 9 \\
1 \cdot 4 \\
1 \cdot 0\end{array}$ & $\begin{array}{r}- \\
1 \cdot 0 \\
1 \cdot 0 \\
1 \cdot 0 \\
1 \cdot 0 \\
6 \cdot 5 \\
4 \cdot 5 \\
8 \cdot 9 \\
18 \cdot 5 \\
17 \cdot 3 \\
37 \cdot 4 \\
56 \cdot 7 \\
80 \cdot 0 \\
64 \cdot 3 \\
65 \cdot 4 \\
54 \cdot 1 \\
28 \cdot 1 \\
22 \cdot 8 \\
21 \cdot 5 \\
5 \cdot 8 \\
3 \cdot 2 \\
2 \cdot 0 \\
1 \cdot 0 \\
-\end{array}$ & $\begin{array}{l}\bar{Z} \\
\overline{1} \cdot 0 \\
\bar{Z} \\
\overline{4} \\
\overline{4} \cdot 0 \\
2.4 \\
2.0 \\
5.0 \\
2.6 \\
4.0 \\
3.0 \\
3.0 \\
\overline{1.0} \\
\overline{1.0} \\
1.0 \\
\bar{Z} \\
\overline{1.0}\end{array}$ & 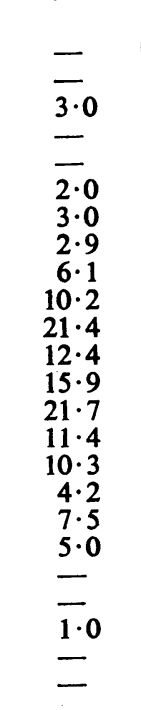 & $\begin{array}{c}\bar{Z} \\
\overline{0} \cdot 4 \\
0.6 \\
\overline{2} \cdot 0 \\
1 \cdot 3 \\
4 \cdot 2 \\
4.8 \\
5.4 \\
11 \cdot 5 \\
12 \cdot 7 \\
7 \cdot 2 \\
12.4 \\
5.6 \\
5.9 \\
2.0 \\
\overline{0.8} \\
0.9 \\
0.9 \\
0.4 \\
= \\
-\end{array}$ \\
\hline Total & $1207 \cdot 0$ & $662 \cdot 0$ & $713 \cdot 0$ & $2582 \cdot 0$ & $502 \cdot 0$ & $31 \cdot 0$ & $138 \cdot 0$ & $79 \cdot 0$ \\
\hline
\end{tabular}

- Fractional frequencies are due to distribution between adjacent groups of weights given to $\neq 1 \mathrm{~b}$. and $\neq 1 \mathrm{~b}$. 
population is numerically very small) so they have been omitted altogether in making the present comparison. Martin shows separately first pregnancies, second pregnancies, and subsequent pregnancies. Order of birth was not ascertained in our sample, so it is necessary to weight his figures, as given in his Table $I$, in order to arrive at single means and standard deviations. In a survey conducted at Bath (Roberts, Norman, and Griffiths, 1938) the birth order of 3,300 schoolchildren was ascertained. Making some allowance for previous stillbirths and deaths, the following weights seem reasonable: first children, 0.33; second, 0.27 ; third and subsequent, $0 \cdot 40$. Even if these weights are somewhat in error for the present sample of children, the differences in the weighted total figures for Martin's series will be very small. Anticipating the next section of this paper, no appreciable difference was found between children attending the various types of school (other than special schools); hence these can be added together. The comparison is shown in Table III.

\section{TABLE III}

Comparison of Birthweights of Normal Sample WITH Martin's ACcurate SAMPLe

\begin{tabular}{|c|c|c|c|c|}
\hline & & & Mean & $\begin{array}{r}\text { Standard } \\
\text { Deviation }\end{array}$ \\
\hline $\begin{array}{l}\text { Martin } \\
\text { Present sample }\end{array}$ & $\begin{array}{l}\cdots \\
\cdots\end{array}$ & $\begin{array}{l}\cdots \\
\cdots\end{array}$ & $\begin{array}{l}7 \cdot 14 \\
7 \cdot 21\end{array}$ & $\begin{array}{l}1 \cdot 19 \\
1 \cdot 30\end{array}$ \\
\hline $\begin{array}{l}\text { Martin } \quad \text { O. } \\
\text { Present sample }\end{array}$ & $\begin{array}{l}\cdots \\
\cdots\end{array}$ & $\begin{array}{l}\cdots \\
\cdots\end{array}$ & $\begin{array}{l}7 \cdot 47 \\
7 \cdot 60\end{array}$ & $\begin{array}{l}1 \cdot 24 \\
1 \cdot 27\end{array}$ \\
\hline
\end{tabular}

The omission of the special school children and the mental defectives from our sample could not, as the proportions of such children are so small, make a difference of as much as one in the last figures shown. A much more important matter is that Martin's sample includes all live births, ours only survivors to various school ages; this must account for some of the difference in means. Allowing for this factor, there is close similarity. In regard to dispersion, the boys of the two series are very similar, but our girls are somewhat more variable; this is due to four of the schools showing an over-variable frequency distribution of birthweights of girls, as is discussed in the following section.

The frequency distributions for the girls and boys at ordinary schools, as shown in Table I above, show considerable departures from the normal form.
In terms of 3rd and 4th moments, the girls show: $\mathrm{g}_{\mathrm{I}}=-0.3131 \pm 0.0520 ; \mathrm{g}_{2}=+1 \cdot 1952 \pm 0 \cdot 1039$ and the boys:

$$
\mathrm{g}_{\mathrm{I}}=-0.0765 \pm 0.0482 ; \mathrm{g}_{2}=+0.6252 \pm 0.0963
$$

Thus in both sexes there is negative skewness, highly significant in the girls, but not attaining the 5 per cent. level in the boys. There is marked and highly significant positive kurtosis in both sexes.

Martin's frequency distributions are not given in a form permitting similar calculations, but it is possible from his Table IV tó compare observed and expected numbers falling into broad groups. It should be mentioned that his Table IV comprises 3,443 boys and 3,269 girls, whereas the means and standard deviations have to be based on the somewhat larger numbers of his Table I, 3,526 boys and 3,329 girls. This cannot, however, make any appreciable difference. In assembling our birthweights into similar broad groups, the group boundaries cannot be made the same as his: $4 \frac{31}{32}$, $5 \frac{31}{32}$. . . $9 \frac{31}{32}$. Ours have to be the slightly higher figures: $5 \frac{1}{4}, 6 \frac{1}{4} \ldots .10 \frac{1}{4}$. In view of our higher means, however, this is probably not a disadvantage. The comparison is shown in Table IV.

The closeness of the correspondence is remarkable, especially in the girls. It is clear that the frequency distribution of human birthweights departs considerably from the normal form, being negatively skewed with positive kurtosis; our series has faithfully reflected this fact.

To sum up the results of this section, a sample of birthweights based on the recollections of mothers of children of various school ages, with all the omissions due to lack of knowledge or forgetfulness, and including all the errors that might have been anticipated, has yielded a frequency distribution which corresponds closely with that of a sample of highly accurate birthweights obtained at a maternity hospital: in means and dispersions showing reasonable agreement; in the actual form of the curve, in type and amount of departure from normality, a remarkably close correspondence. There seems every reason to anticipate that birthweights obtained in this simple and trouble-free way should be reliable enough for the comparison of relatively large groups. So, heartened by this result, we can now proceed with some confidence to examine differences between groups within our sample.

\section{ANALYSIS OF THE DiffFerences BeTWEen SCHOOLS} (OTHER than Special Schools)

In addition to examining the differences between the three types of school containing normal children it seemed advisable to examine also the differences 
TABLE IV

Departures from Normality: Martin's Series and Present Series

\begin{tabular}{|c|c|c|c|c|c|c|c|c|c|}
\hline \multicolumn{5}{|c|}{ Martin's Series } & \multicolumn{5}{|c|}{ Present Series } \\
\hline $\begin{array}{c}\begin{array}{c}\text { Group } \\
\text { boundaries } \\
\text { (lb.) }\end{array} \\
\end{array}$ & $\begin{array}{c}\text { Exptd. } \\
\text { no. }\end{array}$ & $\begin{array}{l}\text { Obs. } \\
\text { no. }\end{array}$ & $\begin{array}{l}\text { Obs.- } \\
\text { exptd. }\end{array}$ & $\chi^{2}$ & $\begin{array}{c}\begin{array}{c}\text { Group } \\
\text { boundaries } \\
(\mathrm{lb} .)\end{array} \\
\end{array}$ & $\begin{array}{c}\text { Exptd. } \\
\text { no. }\end{array}$ & $\begin{array}{c}\text { Obs. } \\
\text { no. }\end{array}$ & $\begin{array}{l}\text { Obs.- } \\
\text { exptd. }\end{array}$ & $\chi^{2}$ \\
\hline Girls & $111: 4$ & 125 & $+13 \cdot 6$ & $1 \cdot 660$ & \multirow{2}{*}{51} & $144 \cdot 8$ & $155 \cdot 9$ & $+11 \cdot 1$ & $0 \cdot 851$ \\
\hline $4 \frac{3}{2}$ & $446 \cdot 1$ & 361 & $-85 \cdot 1$ & $16 \cdot 234$ & & $363 \cdot 2$ & $269 \cdot 0$ & $-94 \cdot 2$ & $24 \cdot 432$ \\
\hline $5 \frac{3 \cdot 1}{2}$ & $974 \cdot 1$ & 910 & $-64: 1$ & $4 \cdot 218$ & 64 & $625 \cdot 8$ & $669 \cdot 8$ & $+44 \cdot 0$ & 3.094 \\
\hline \multirow{2}{*}{$7 \frac{31}{3}$} & $1039 \cdot 1$ & 1,191 & $+151 \cdot 9$ & $22 \cdot 205$ & \multirow{2}{*}{84} & $613 \cdot 0$ & $697 \cdot 0$ & $+84 \cdot 0$ & $11 \cdot 511$ \\
\hline & $541 \cdot 8$ & 543 & $+1 \cdot 2$ & 0.003 & & $341 \cdot 6$ & $317 \cdot 2$ & $-24 \cdot 4$ & $1 \cdot 743$ \\
\hline \multirow{2}{*}{$9 \frac{31}{3}$} & $138 \cdot 3$ & 122 & $-16 \cdot 3$ & $1 \cdot 921$ & \multirow{2}{*}{$10 \frac{1}{4}$} & $108 \cdot 1$ & $92 \cdot 9$ & $-15 \cdot 2$ & $2 \cdot 137$ \\
\hline & $18 \cdot 2$ & 17 & $-1 \cdot 2$ & 0.079 & & $21 \cdot 5$ & $16 \cdot 2$ & $-5 \cdot 3$ & $1 \cdot 307$ \\
\hline & $3269 \cdot 0$ & 3,269 & & $46 \cdot 320$ & & $2218 \cdot 0$ & $2218 \cdot 0$ & & $.45 \cdot 075$ \\
\hline \multirow[b]{2}{*}{$4 \frac{31}{2}$} & $77 \cdot 8$ & 78 & +0.2 & $0.001^{\mathrm{Bo}}$ & & $81 \cdot 9$ & $98 \cdot 5$ & $+16 \cdot 6$ & $3 \cdot 365$ \\
\hline & $345 \cdot 1$ & 305 & $-40 \cdot 1$ & $4 \cdot 660$ & & $287 \cdot 3$ & $214 \cdot 8$ & $-72 \cdot 5$ & $18 \cdot 295$ \\
\hline $5 \frac{31}{2}$ & $866 \cdot 4$ & 810 & $-56 \cdot 4$ & $3 \cdot 671$ & 64 & $640 \cdot 1$ & $660 \cdot 6$ & +20.5 . & 0.657 \\
\hline $6 \frac{8}{3} \frac{1}{2}$ & $1117 \cdot 9$ & 1,195 & $+77 \cdot 1$ & $5 \cdot 317$ & 71 & $786 \cdot 9$ & $864 \cdot 6$ & $+77 \cdot 7$ & $7 \cdot 672$ \\
\hline \multirow{2}{*}{$\begin{array}{l}7 \frac{8}{2} \\
8 \frac{3}{2}\end{array}$} & $738 \cdot 2$ & 760 & $+21 \cdot 8$ & 0.644 & \multirow{3}{*}{$\begin{array}{r}91 \\
104\end{array}$} & $536 \cdot 7$ & $511 \cdot 8$ & $-24 \cdot 9$ & $1 \cdot 155$ \\
\hline & $250 \cdot 3$ & 242 & $-8 \cdot 3$ & $0 \cdot 275$ & & $201 \cdot 9$ & $184 \cdot 1$ & $-17 \cdot 8$ & $1 \cdot 569$ \\
\hline \multirow{2}{*}{$9 \frac{31}{3}$} & $47 \cdot 3$ & 53 & $+5 \cdot 7$ & $0 \cdot 687$ & & $47 \cdot 2$ & $47 \cdot 6$ & +0.4 & 0.003 \\
\hline & $3443 \cdot 0$ & 3,443 & & $15 \cdot 255$ & & $2582 \cdot 0$ & $2582 \cdot 0$ & & $32 \cdot 716$ \\
\hline
\end{tabular}

Degrees of freedom=4; Martin, boys, $\mathrm{P}<0.01$; remainder, $\mathrm{P}<0.001$.

between schools of the same type, thus making some assessment of the internal consistency of the figures. The means and standard deviations for the 14 schools are shown in Table V. Thirteen were mixed schools; one was a boys' school.

An analysis of the variation of the means is presented in Table VI.

It will be seen that the school means for the girls do not reveal any evidence of significant heterogeneity, either between school types, or between schools within school types. There is significant, though not highly, significant. variation between school types amongst.the boys. This is due to the secondary modern boys (i.e. the dullest) being somewhat heavier than the remainder. As, however, the secondary modern girls attending the same schools are slightly lighter than the remainder, it does not seem necessary to attach any importance to this moderate discrepancy. As in the girls, schools of the same type are homogeneous.

The homogeneity of the variances may be examined by Bartlett's method (1937). For the boys $-2 \log \mu$ is $5 \cdot 22$; this is distributed as $\chi^{2}$ for $\odot$ 13 degrees of freedom and so the school variances $N$ are perfectly homogeneous. It is the more remark- N able to find, therefore, that the school variances of 0 the girls are distinctly heterogeneous; $-2 \log \mu$ is $42 \cdot 33$, which with 12 degrees of freedom is highly significant. Actually, the heterogeneity is entirely $\stackrel{?}{?}$ due to four schools, one primary and three secondary 0 modern, which are far more variable in their $\overline{0}$ birthweights than the rest. This, of course, makes the secondary modern birthweights significantly more variable than those of the other types of school 
TABLE V

Birthweights of Normal Children. Numbers, Means, and Standard Deviations, Separately by Schools

\begin{tabular}{|c|c|c|c|c|c|c|}
\hline & \multicolumn{3}{|c|}{ Girls } & \multicolumn{3}{|c|}{ Boys } \\
\hline School & No. & Mean & $\begin{array}{l}\text { Standard } \\
\text { Deviation }\end{array}$ & No. & Mean & $\begin{array}{c}\text { Standard } \\
\text { Deviation }\end{array}$ \\
\hline $\begin{array}{r}\text { Primary } \\
1 \\
2 \\
3 \\
4 \\
5 \\
6 \\
7\end{array}$ & $\begin{array}{r}245 \\
113 \\
236 \\
180 \\
99 \\
173 \\
154\end{array}$ & $\begin{array}{l}7 \cdot 270 \\
7 \cdot 151 \\
7 \cdot 133 \\
7 \cdot 119 \\
7 \cdot 209 \\
7 \cdot 116 \\
7 \cdot 245\end{array}$ & $\begin{array}{l}1 \cdot 149 \\
1 \cdot 218 \\
1 \cdot 325 \\
1 \cdot 199 \\
1 \cdot 237 \\
1 \cdot 212 \\
1 \cdot 387\end{array}$ & $\begin{array}{l}221 \\
135 \\
254 \\
184 \\
117 \\
151 \\
145\end{array}$ & $\begin{array}{l}7 \cdot 429 \\
7 \cdot 559 \\
7 \cdot 638 \\
7 \cdot 510 \\
7 \cdot 624 \\
7 \cdot 523 \\
7 \cdot 527\end{array}$ & $\begin{array}{l}1 \cdot 260 \\
1 \cdot 305 \\
1 \cdot 258 \\
1 \cdot 228 \\
1 \cdot 363 \\
1 \cdot 248 \\
1 \cdot 245\end{array}$ \\
\hline Total & 1,200 & $7 \cdot 179$ & $1 \cdot 245$ & 1,207 & $7 \cdot 542$ & $1 \cdot 266$ \\
\hline $\begin{array}{c}\text { Secondary } \\
\text { Grammar } \\
1 \\
2 \\
3\end{array}$ & $\begin{array}{l}184 \\
180 \\
-\end{array}$ & $\begin{array}{c}7 \cdot 367 \\
7 \cdot 307 \\
-\end{array}$ & $\begin{array}{c}1 \cdot 162 \\
1 \cdot 184 \\
-\end{array}$ & $\begin{array}{l}153 \\
166 \\
343\end{array}$ & $\begin{array}{l}7 \cdot 615 \\
7 \cdot 687 \\
7 \cdot 534\end{array}$ & $\begin{array}{l}1 \cdot 196 \\
1 \cdot 310 \\
1 \cdot 250\end{array}$ \\
\hline Total & 364 & $7 \cdot 337$ & $1 \cdot 172$ & 662 & $7 \cdot 591$ & $1 \cdot 253$ \\
\hline $\begin{array}{c}\text { Secondary } \\
\text { Modern } \\
1 \\
2 \\
3 \\
4\end{array}$ & $\begin{array}{l}. \\
203 \\
122 \\
212 \\
117\end{array}$ & $\begin{array}{l}7 \cdot 239 \\
7 \cdot 393 \\
7 \cdot 072 \\
7 \cdot 206\end{array}$ & $\begin{array}{l}1 \cdot 472 \\
1 \cdot 283 \\
1.531 \\
1 \cdot 423\end{array}$ & $\begin{array}{l}193 \\
168 \\
236 \\
116\end{array}$ & $\begin{array}{l}7 \cdot 786 \\
7 \cdot 716 \\
7 \cdot 702 \\
7 \cdot 591\end{array}$ & $\begin{array}{l}1 \cdot 263 \\
1 \cdot 283 \\
1 \cdot 318 \\
1 \cdot 199\end{array}$ \\
\hline Total & 654 & $7 \cdot 208$ & $1 \cdot 451$ & 713 & $7 \cdot 710$ & $1 \cdot 275$ \\
\hline $\begin{array}{c}\text { Total—all } \\
\text { schools }\end{array}$ & 2,218 & $7 \cdot 213$ & $1 \cdot 299$ & 2,582 & $7 \cdot 601$ & $1 \cdot 267$ \\
\hline
\end{tabular}

TABLE VI

Analysis of Variance. Children attending Normal Schools

Girls

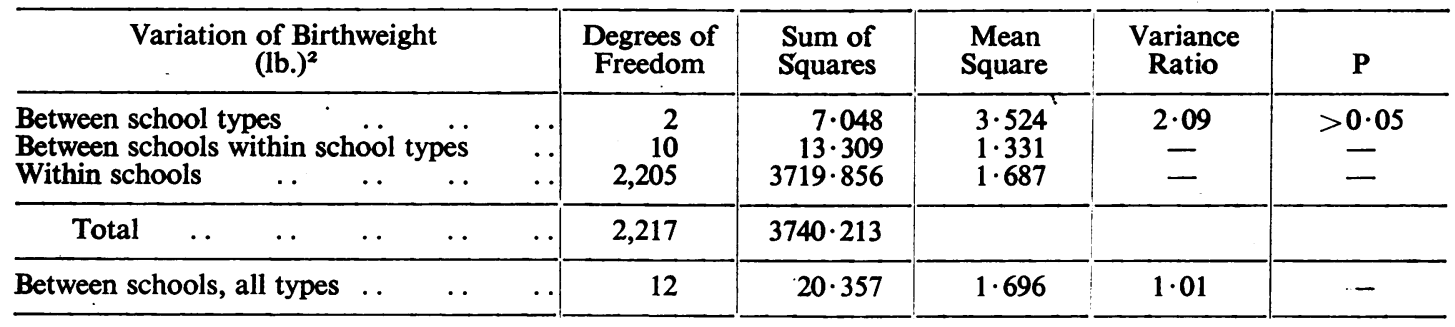

Boys

\begin{tabular}{|c|c|c|c|c|c|c|c|c|}
\hline \multicolumn{4}{|c|}{$\begin{array}{c}\text { Variation of Birthweight } \\
\text { (lb.) })^{2}\end{array}$} & $\begin{array}{l}\text { Degrees of } \\
\text { Freedom }\end{array}$ & $\begin{array}{l}\text { Sum of } \\
\text { Squares }\end{array}$ & $\begin{array}{l}\text { Mean } \\
\text { Square }\end{array}$ & $\begin{array}{l}\text { Variance } \\
\text { Ratio }\end{array}$ & $\mathbf{P}$ \\
\hline \multicolumn{3}{|c|}{$\begin{array}{l}\text { Between school types } \\
\text { Between schools within school types } \\
\text { Within schools } \quad . . \quad \ldots \quad \ldots\end{array}$} & & $\begin{array}{r}2 \\
11 \\
2,568 \\
\end{array}$ & $\begin{array}{r}12 \cdot 693 \\
11 \cdot 807 \\
4115 \cdot 577\end{array}$ & $\begin{array}{l}6 \cdot 347 \\
1 \cdot 073 \\
1 \cdot 603\end{array}$ & $\frac{3.96}{-}$ & $\begin{array}{c}0.05-0.01 \\
二\end{array}$ \\
\hline Total & $\cdots$ & . & & 2,581 & $4140 \cdot 077$ & & & \\
\hline \multicolumn{3}{|c|}{ Between schools, all types } & & 13 & $24 \cdot 500$ & $1 \cdot 885$ & $1 \cdot 18$ & - \\
\hline
\end{tabular}


and also the whole sample of girls more variable than the boys. If the three largest variances are omitted $-2 \log \mu$ is reduced to $12 \cdot 10$ and so becomes non-significant. It is very curious that the girls at these four schools should be so variable in birthweight, whereas the boys attending the same four schools-drawn from the same areas and often from the same families-should show no such difference. We have no explanation to offer and the finding remains a disturbing one.

Reviewing the evidence as a whole we are disposed to conclude that it is safe to use the material for the comparison of large groups; the homogeneity of the school means in the girls, with only a slight departure in regard to school types in the boys, and the homogeneity of the school variances in the boys, do seem to point to a body of data that is sufficiently reliable for this purpose, even though four schools are over-variable in the birthweights of the girls. And, of course, there is the more important fact of close correspondence with Martin's accurate measurements dealt with in the preceding section.

\section{LACK OF AsSociation BeTWEen BiRTHWEIGHT AND} INTELLIGENCE IN NORMAL SCHOOLCHILDREN

The results of the preceding section show that there is no appreciable difference between the mean birthweights of children attending the three types of school. To summarize the figures:

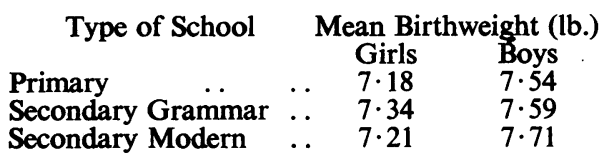

If there were an association between high intelligence and high birthweight, primary school children would $\mathbb{D}$ be expected to give a mean figure representative of $\%$ the whole population, whereas secondary grammar $\overrightarrow{\vec{c}}$ school children would be higher and secondarymodern children lower. Yet with a difference in mean intelligence of well over a standard deviation $\bar{\omega}$ there is no indication of any corresponding difference $\widehat{\Phi}$ in birthweight. It can be safely concluded, therefore, that in the general normal population there ${ }^{\infty}$ can be no appreciable correlation between birth- $\vec{O}$ weight and intelligence.

Anticipating the next section, it may be asked $\omega_{\sigma}$ whether there is any indication that there is a higher $\frac{0}{0}$ proportion of low birthweights amongst the $\frac{\rho}{9}$ secondary modern children compared with the $\omega$ secondary grammar school children. The figures ir show:

Percentage of children below음

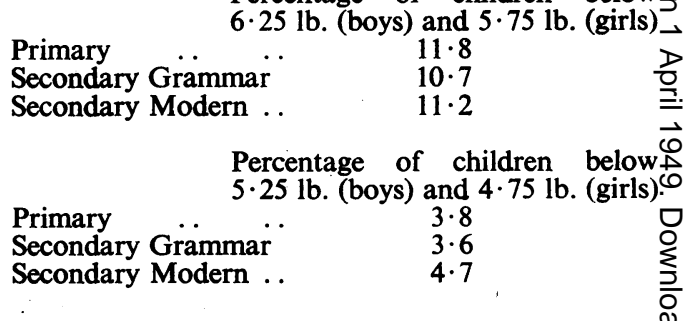

This last difference between the secondary grammarő and secondary modern schools is not significant $\stackrel{\mathbb{Q}}{2}$ $\left(\chi^{2}=1 \cdot 89\right)$. Some caution is needed in interpreting $\overrightarrow{\overrightarrow{0}}$ this finding. The proportion of children at special 3 schools is so small that even if they were all included $\vec{F}$ with the secondary modern children, the figures

TABLE VII

Birthweights of Special School Children. Numbers, Means, and Standard Deviations, separately by SCHOOLS

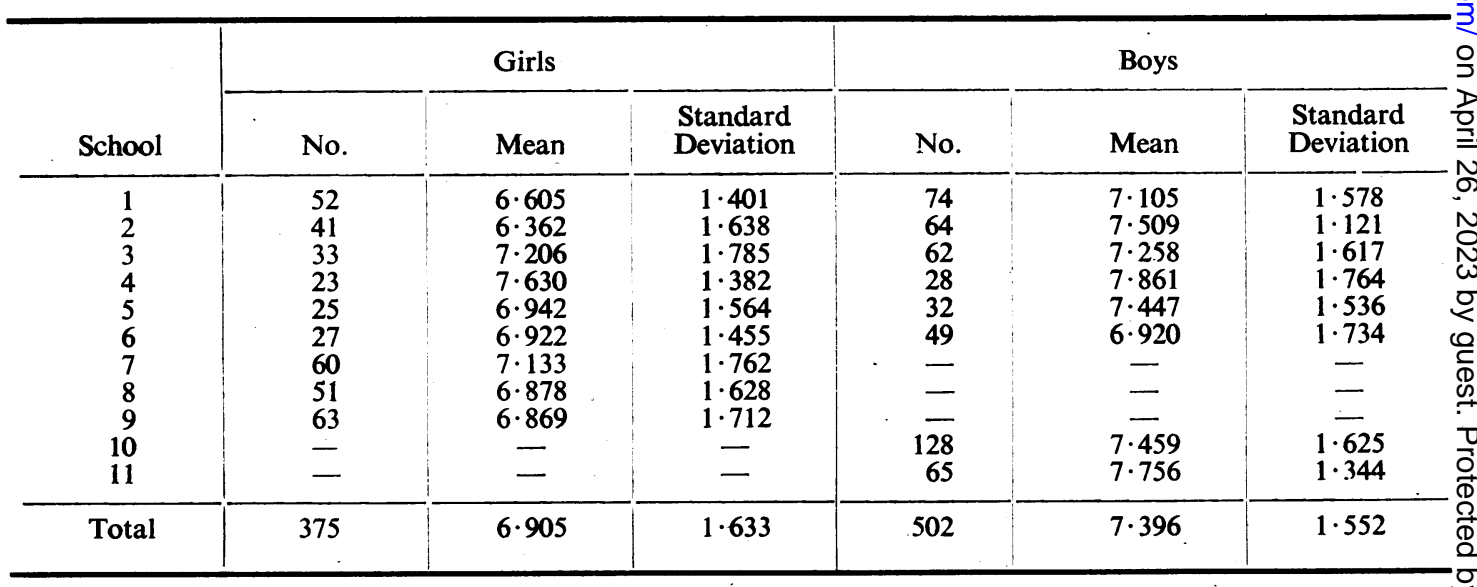


would not be appreciably changed. Secondary modern schools contain some children whose intelligence is almost as low, or fully as low, as that of some children at special schools. It cannot be deduced that this small fraction of the very dull does not include an undue proportion of very low birthweights; relatively enormous numbers would be needed, however, to decide the point. What can be deduced is that the separation of children into the brighter fraction destined for secondary grammar schools and the duller fraction destined for secondary modern schools has no counterpart in any appreciable excess of low birthweights in the latter type of school. In other words, a measurable excess of low birthweights is found only in that portion of the range comprising relatively very low intelligences.

\section{Homogeneity of the Special Schools in Regard TO BIRTHWEIGHT}

Eleven special schools have been included in this study, three being girls' schools, two boys' schools, and six mixed schools. The means and standard deviations are shown separately by schools in Table VII.

Table VIII shows the analysis of variance.

Again using Bartlett's method for testing the homogeneity of the variances, $-2 \log \mu$ is 5.51 for the girls and 16.09 for the boys, distributed as $\chi^{2}$ for 8 and 7 degrees of freedom respectively.

The girls are therefore perfectly homogeneous in regard both to school means and variances. With the boys there is heterogeneity which just attains the 0.05 level of significance for school means and somewhat exceeds it for variances. This seems a satisfactory result, as some evidence of heterogeneity, considerably more pronounced than has actually been found, would not have been surprising. The special schools cover a wide area and in view of variations in local policy it might well be that different schools tend to receive rather different types of pupil.

\section{Birthweights of Special School and Mentally Defective ChildRen}

In view of the uniformity of the mean birthweights of children at primary, secondary grammar, and secondary modern schools, these can be added together for comparison with the birthweights of the special school children and the certified mental defectives. The comparison is shown in Table IX. The retarded children are lighter and more variable. The differences between the normal children and the special school samples are significant, highly so in the boys. The numbers of mental defectives are not sufficient for the differences to attain the level of significance, but the same trend is plain.

Inspection of Table II shows that these differences are not due to a shifting of the whole curve, but to a large excess of very low birthweights amongst the backward children, together with a much smaller excess of very large weights. Within the region $6 \cdot 25-10 \cdot 75 \mathrm{lb}$. in the boys and $5 \cdot 75-10 \cdot 25 \mathrm{lb}$. in the girls all three distributions are practically identical. This comparison is shown in Table $\mathbf{X}$.

If, then, the low, and very high weights are omitted,

TABLE VIII

ANalysis of Variance (Children attending Special Schools)

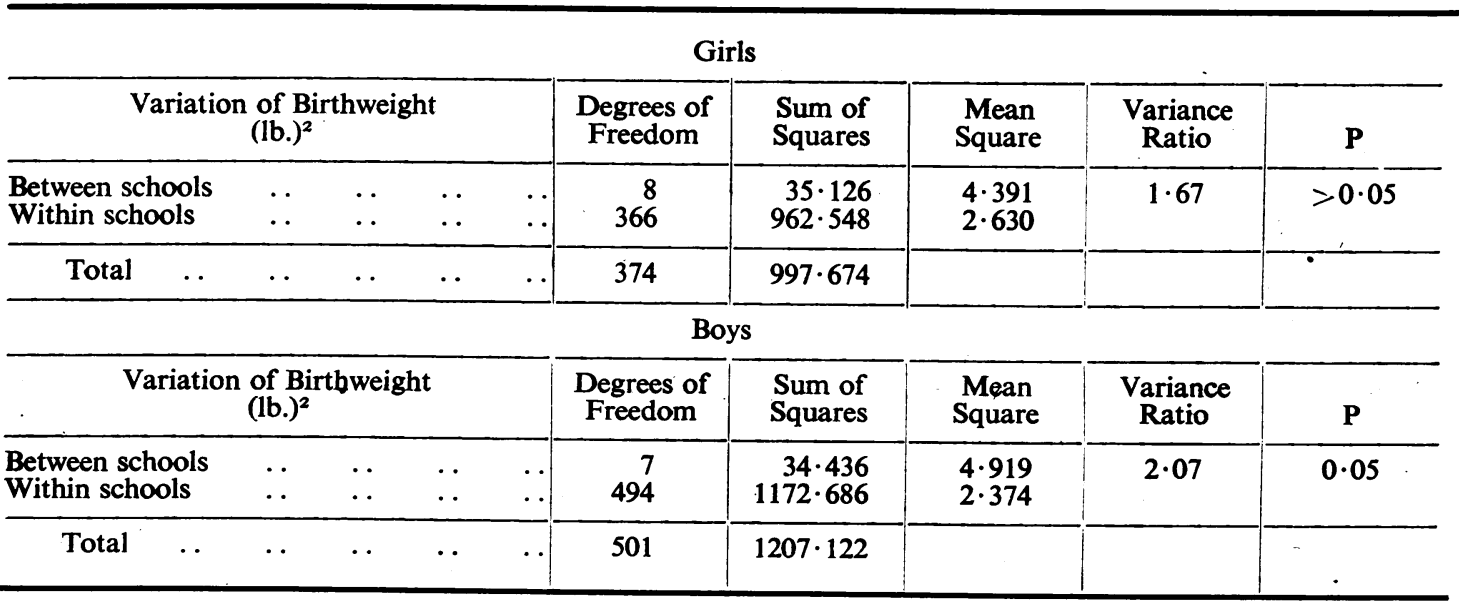


TABLE DX

Birthweights of Normal, Special School, and Mentally Defective Children. Numbers, Means, and StaNDARD DeVIATIONS

\begin{tabular}{|c|c|c|c|c|c|c|}
\hline \multirow[b]{2}{*}{ Type of School } & \multicolumn{3}{|c|}{ Girls } & \multicolumn{3}{|c|}{ Boys } \\
\hline & No. & Mean & $\begin{array}{c}\text { Standard } \\
\text { Deviation }\end{array}$ & No. & Mean & $\begin{array}{l}\text { Standard } \\
\text { Deviation }\end{array}$ \\
\hline $\begin{array}{l}\text { Normal } \\
\text { Special Schooi } \\
\text { Mentally }\end{array}$ & $\begin{array}{r}2,218 \\
375\end{array}$ & $\begin{array}{l}7 \cdot 213 \\
6 \cdot 905\end{array}$ & $\begin{array}{l}1 \cdot 299 \\
1 \cdot 633\end{array}$ & $\begin{array}{r}2,582 \\
502\end{array}$ & $\begin{array}{l}7 \cdot 601 \\
7 \cdot 396\end{array}$ & $\begin{array}{l}1 \cdot 267 \\
1 \cdot 552\end{array}$ \\
\hline Defective & 95 & $6 \cdot 752$ & $1 \cdot 826$ & 248 & $7 \cdot 368$ & 1.698 \\
\hline
\end{tabular}

TABLE $X$

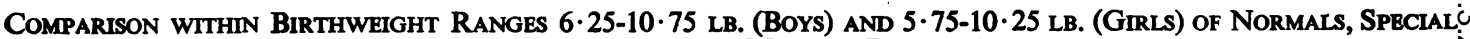
School Pupils, and Mental Defectives

\begin{tabular}{|c|c|c|c|c|c|c|}
\hline \multirow[b]{2}{*}{ Type of School } & \multicolumn{3}{|c|}{ Girls } & \multicolumn{3}{|c|}{ Boys } \\
\hline & No.* & Mean & $\begin{array}{l}\text { Standard } \\
\text { Deviation }\end{array}$ & No.* & Mean & $\begin{array}{l}\text { Standard } \\
\text { Deviation }\end{array}$ \\
\hline $\begin{array}{l}\text { Normal } \\
\text { Special School } \\
\text { Mentally } \\
\text { Defective .. }\end{array}$ & $\begin{array}{r}1967 \cdot 5 \\
295 \cdot 9 \\
67 \cdot 4\end{array}$ & $\begin{array}{l}7 \cdot 475 \\
7 \cdot 403 \\
7 \cdot 605\end{array}$ & $\begin{array}{l}0.949 \\
1.006 \\
1.031\end{array}$ & $\begin{array}{r}2253 \cdot 9 \\
398 \cdot 7 \\
188 \cdot 5\end{array}$ & $\begin{array}{l}7 \cdot 876 \\
7 \cdot 874 \\
7 \cdot 866\end{array}$ & $\begin{array}{l}0.978 \\
1.043 \\
1.083\end{array}$ \\
\hline
\end{tabular}

* Fractional frequencies are due to distribution between adjacent groups of weights given to $t \mathbf{l b}$. and $\frac{g}{\mathbf{z}} \mathbf{l b}$.

the differences in means vanish, none being significant. The backward children are still slightly more variable, but the differences are very small compared with those shown for the total frequency distributions in Table IX. Adding together the special school and mentally defective children, the variances are as follows:

\begin{tabular}{|c|c|c|}
\hline $\begin{array}{l}\text { Normal children .. } \\
\text { Backward children }\end{array}$ & $\begin{array}{c}\text { Girls } \\
0 \cdot 9011 \\
1 \cdot 0255\end{array}$ & $\begin{array}{c}\text { Boys } \\
0 \cdot 9557 \\
1 \cdot 1132\end{array}$ \\
\hline Differenc & $\begin{array}{l}0.1244 \\
\pm 0.0732\end{array}$ & $\begin{array}{l}0.1575 \\
\pm 0.0632\end{array}$ \\
\hline
\end{tabular}

The difference is not significant in the girls, but in the boys it is 2.49 times its standard error. The curtailing of the frequency distributions has, of course, produced marked negative kurtosis, so reducing the standard errors of the variances. This has been allowed for by using the fourth cumulants.

Thus over a portion of the range that includes some 88 per cent. of normal children, there is no difference in means between normal children, special school children, and certified mental defectives. The backward children are still very slightly more variable, but the omission of the low birthweights and of a very small proportion of high birthweights has reduced the original large differ ences to very small limits.

Turning now to the birthweights below $6 \cdot 25 \mathrm{lb}$ in boys and $5.75 \mathrm{lb}$. in girls, we find the following percentages below these limits:

\begin{tabular}{|c|c|c|c|}
\hline & $\begin{array}{l}\text { Girls } \\
10 \cdot 6\end{array}$ & $\begin{array}{l}\text { Boys } \\
12 \cdot 1\end{array}$ & $\begin{array}{c}\text { Both Sexes } \\
11 \cdot 4\end{array}$ \\
\hline & $19 \cdot 3$ & $19 \cdot 3$ & $19 \cdot 3$ \\
\hline tives & $30 \cdot 7$ & $21 \cdot 2$ & $23 \cdot 7$ \\
\hline
\end{tabular}

The excess of low birthweights amongst both kinds of backward children is very pronounced. (It) should be noted that the number of mentall defective girls is very small.)

In order to make a finer comparison it seems best? to treat both sexes together, adding the small samples of feeble-minded to the special school sample (the range of I.Q.s is not very dissimilar) and also taking idiots and imbeciles together, as they are too few te separate usefully. The results are shown in Table XIe The same figures are shown in Table XII, but thi\$ time as relative proportions, the percentage off birthweights of normal children falling into eact frequency group being taken as 100 .

There is a steady increase in the disproportion a 
TABLE XI

Comparison of Percentages of Low Birthweights in Normal and Retarded Children

\begin{tabular}{|c|c|c|c|c|}
\hline \multicolumn{2}{|c|}{ Group Boundaries (lb.) } & \multirow{2}{*}{$\frac{\text { Normal }}{(\text { Total } 4,800)}$} & \multirow{2}{*}{$\begin{array}{c}\begin{array}{c}\text { Special School and } \\
\text { Feeble-minded }\end{array} \\
\text { (Total 923) }\end{array}$} & \multirow{2}{*}{$\begin{array}{c}\text { Idiots and Imbeciles } \\
\text { (Total 297) }\end{array}$} \\
\hline Girls & Boys & & & \\
\hline $\begin{array}{c}4 \cdot 75-5 \cdot 75 \\
3 \cdot 75-4 \cdot 75 \\
2 \cdot 75-3 \cdot 75 \\
<2 \cdot 75 \\
\end{array}$ & $\begin{array}{l}5 \cdot 25-6 \cdot 25 \\
4 \cdot 25-5 \cdot 25 \\
3 \cdot 25-4 \cdot 25 \\
<3 \cdot 25\end{array}$ & $\begin{array}{l}7 \cdot 42 \\
2 \cdot 95 \\
0 \cdot 73 \\
0 \cdot 31\end{array}$ & $\begin{array}{r}10 \cdot 25 \\
5 \cdot 37 \\
2 \cdot 58 \\
1 \cdot 19\end{array}$ & $\begin{array}{r}13 \cdot 60 \\
5 \cdot 62 \\
2 \cdot 83 \\
1 \cdot 68\end{array}$ \\
\hline$<5 \cdot 75$ & $<6 \cdot 25$ & $11 \cdot 41$ & $19 \cdot 39$ & $23 \cdot 73$ \\
\hline
\end{tabular}

TABLE XII

Proportions of Low Birthweights in Retarded Children with Proportions in Normals fixed at 100

\begin{tabular}{|c|c|c|c|c|}
\hline \multicolumn{2}{|c|}{ Group Boundaries (lb.) } & \multirow{2}{*}{ Normal } & \multirow{2}{*}{$\begin{array}{l}\text { Special School and } \\
\text { Feeble-minded }\end{array}$} & \multirow{2}{*}{ Idiots and Imbeciles } \\
\hline Girls & Boys & & & \\
\hline $\begin{array}{c}4 \cdot 75-5 \cdot 75 \\
3 \cdot 75-4 \cdot 75 \\
2 \cdot 75-3 \cdot 75 \\
<2 \cdot 75\end{array}$ & $\begin{array}{c}5 \cdot 25-6 \cdot 25 \\
4 \cdot 25-5 \cdot 25 \\
3 \cdot 25-4 \cdot 25 \\
<3 \cdot 25\end{array}$ & $\begin{array}{l}100 \\
100 \\
100 \\
100\end{array}$ & $\begin{array}{l}138 \\
182 \\
353 \\
384 \\
\end{array}$ & $\begin{array}{l}183 \\
191 \\
388 \\
542 \\
\end{array}$ \\
\hline$<5 \cdot 75$ & $<6 \cdot 25$ & 100 & 170 & 208 \\
\hline
\end{tabular}

birthweight falls. There are four times as many birthweights under $2.75 \mathrm{lb}$. for girls and $3.25 \mathrm{lb}$. for boys as in the normal series and this disproportion becomes steadily less with each increase of one pound in weight.

The difference between special school children and the feeble-minded on the one hand and idiots and imbeciles on the other is smaller than might have been anticipated. There does appear, however, to be a slightly higher proportion of small birthweights amongst the low grade defectives, but our series is too small to pursue this point further. The chief finding, as far as our figures go, is that an excess of low birthweights seems to be almost as strongly associated with high grade mental deficiency as with idiocy and imbecility.

Examination of Table I suggests that perhaps one should go a little higher than the limits chosen in this paper before all discrepancy vanishes; but to add another half-pound, including as low weights girls under $6.25 \mathrm{lb}$. and boys under $6.75 \mathrm{lb}$., would make the comparison worse, not better, as is shown by the first results of this section. Similarly, half a pound is slightly too big a difference to make between the sexes. In these matters, however, we are limited by our grouping of birthweights, to which there was no alternative.

It remains to compare the very high weights, which we have fixed, after inspection of the frequency distributions, as above $10 \cdot 25 \mathrm{lb}$. for girls and $10.75 \mathrm{lb}$. for boys. Here the figures are so small that we have added together the special school and mental defective samples. The comparison is shown in Table XIII.

It seems best to compare the large birthweights with those within that range over which normal and backward children do not differ. The excess of large weights amongst the backward children is significant in the girls $\left(\chi^{2}=4 \cdot 74\right)$ and highly so in the boys $\left(\chi^{2}=10 \cdot 12\right)$. It should be recalled, however, that the mothers of the backward children are themselves, on the average, of lower intelligence than the mothers of the normal series, and so there might be rather more mistakes amongst the birthweights as given by them. It is very unlikely indeed that the difference can be explained in this way, but with small absolute numbers it is perhaps necessary to be cautious and to await the collection of more ample data before accepting this finding without some reservation. 
TABLE XIII

Comparison of Normal and Backward ChILdRen of Very LaRge Weights

\begin{tabular}{|c|c|c|c|c|c|c|}
\hline & & Girls & & & Boys & \\
\hline & 5.75- $10.25 \mathrm{lb}$. & $\begin{array}{l}\text { No.* over } \\
10.25 \mathrm{lb} \text {. }\end{array}$ & $\begin{array}{c}\text { Percentage } \\
\text { over } 10.25 \mathrm{lb} \text {. }\end{array}$ & $\begin{array}{c}\text { No.* } \\
6.25-10.75 \mathrm{lb} .\end{array}$ & $\begin{array}{l}\text { No.* over } \\
10.75 \mathrm{lb} \text {. }\end{array}$ & $\begin{array}{c}\text { Percentage } \\
\text { over } 10.75 \mathrm{lb} .\end{array}$ \\
\hline $\begin{array}{l}\text { Normal } \\
\text { Backward }\end{array}$ & $\begin{array}{r}1967 \cdot 5 \\
363 \cdot 3\end{array}$ & $\begin{array}{r}16 \cdot 2 \\
7 \cdot 6\end{array}$ & $\begin{array}{l}0 \cdot 82 \\
2 \cdot 05\end{array}$ & $\begin{array}{r}2253 \cdot 9 \\
587 \cdot 2\end{array}$ & $\begin{array}{l}14 \cdot 8 \\
12 \cdot 4\end{array}$ & $\begin{array}{l}0.65 \\
2 \cdot 07\end{array}$ \\
\hline
\end{tabular}

* Fractional frequencies are due to distribution between adjacent groups of weights given to $₫ \mathrm{lb}$. and $q \mathrm{lb}$.

Low and High Birthweights in Relation to Mental Retardation

It would seem, then, if our conclusions are soundly based, that there is no appreciable general relation between birthweight and intelligence; even idiots and imbeciles show no tendency to be lighter at birth than gifted children; there is no shifting of the frequency curve. But mental defectives and very backward children do include a substantial excess of low birthweights and a small excess of very high ones. It is tempting, though not of course justifiable on the data of this paper, to translate these findings into the simple statement that very backward children differ from others in regard to birthweight simply in being more often premature or postmature.

Considering the low weights first, this study provides no evidence as to whether babies destined to be mentally defective tend to be more often premature than do normal children, or whether the prematurity (or immaturity) is the cause of the mental deficiency. In all probability both are true. Prematurity with its associated fragile blood-vessels predisposes to intracranial haemorrhage, and it would not be surprising to find that the bulk of the excess is due to mental deficiency which is a consequence of the prematurity. If the whole of the excess were to be explained in this way, our figures would indicate that some 7 per cent. of mental deficiency amongst children of school age is to be ascribed to this cause. This is likely to prove an overestimate; but we do feel that a smaller, though not negligible, fraction may well be so caused. If this is true, it is an important fraction, for unlike so much else in the causation of mental deficiency, this is a factor which offers the promise of control and improvement.

As regards the excess of very large babies amongst the defectives, it is difficult not to ascribe this directly to the resulting difficult labour and greater liability to birth injury. Our figures indicate that
1 per cent. of mental deficiency may be caused in this way.

It has already been pointed out that the defective and special school fractions are relatively small numerically. Hence the observed excess of low weights amongst these children does not mean a bad prognosis as regards subsequent mentality for the individual premature child. Even below $3.25 \mathrm{lb}$. for girls and $2.75 \mathrm{lb}$. for boys, where the percentage is multiplied fourfold as compared with normal schoolchildren, the likelihood that any given child below these limits will be mentally defective should not exceed 10 per cent. But it is not without significance, perhaps, that of the only two children with birthweights of $1 \frac{1}{2} \mathrm{lb}$. in our 6,000 (both checked and found to be correct), one was at a special school and the other was an imbecile.

These findings seem to agree well with studies on the development of immature or premature babies. As already mentioned, the literature has recently been summarized by one of us (Asher, 1946). On the whole there is a rather remarkable agreement on the facts, namely, that a proportion of such children which may be estimated very roughly at 10 per cent. is mentally defective or very backward. To select one careful study as an example, Rosanoff and Inman-Kane (1934) found that $10 \cdot 3$ per cent. of their 381 subjects had I.Q.s below 76. Where the $\rightarrow$ various writers differ is not so much on the facts, but in the point of view from which they regard $N$ them. Some, the pessimists, point out that the proportion of mental deficiency is far higher than in children of normal birthweight; others, the $\omega$ optimists, are more impressed by the fact that any given premature child is much more likely to grow up with normal mentality than to be mentally defective.

A striking, and perhaps surprising, point about the present study is that low birthweight seems to be almost if not quite as strongly associated with feeble-mindedness and pronounced backwardness 
as it is with gross damage resulting in idiocy or imbecility. But once again this is in harmony with the findings in the previous study (Asher, 1946) and apparently with the literature generally.

It may not be out of place to say a word about the accepted figure of $5 \frac{1}{2} \mathrm{lb}$. as marking the limit of immaturity. First, this study, as well as others, indicates that a sex difference should be made. Karn (1947) suggests that the limit should be $0.25 \mathrm{lb}$. higher for boys; the present study indicates a slightly larger difference, about $0.4 \mathrm{lb}$. Further refinements might well include adjustments for parity and also in the case of twins, though these are somewhat less important. Secondly, at least from the point of view of some association with subsequent mental impairment, the accepted limit is a little low. As has been shown above, there is evidence of some unfavourable effect up to about $5.75 \mathrm{lb}$. for girls and about $6 \cdot 25 \mathrm{lb}$. for boys.

As regards low and high weights and their association with mental deficiency, this is a preliminary study. We have made no attempt to subdivide the defective children by types, or, except very roughly, by grade. Our figures are too small for this. Far larger numbers are needed and, coupled with this, much more detail. There would seem to be good indications that further studies on these lines should lead to useful results.

\section{SUMMARY}

1. A sample of 4,800 birthweights of children attending primary, secondary grammar, and secondary modern schools was obtained by questioning the mothers. The frequency distributions corresponded very closely to those of Martin's series of birthweights accurately measured at a maternity hospital; the resemblance between the two series extended to means, dispersions, and to the type and amount of departure from normality. The individual school means and variances were satisfactorily homogeneous except that for some unexplained reason the girls at four schools were over-variable. It is concluded that birthweights obtained in this way can safely be used for certain purposes, such as the comparison of the means of large groups.

2. There was no appreciable difference between the birthweights of children attending the three types of school. As secondary grammar and secondary modern children differ by more than a standard deviation of Binet I.Q., it is concluded that there can be no appreciable association between birthweight and intelligence in the general population taken as a whole.
3. A sample of birthweights of children attending special schools for the educationally subnormal, and also a sample of certified mental defectives, had lower mean birthweights and also showed more variability than the normal children. These differences are entirely due to an excess of very low birthweights amongst the backward children, together with a very much smaller excess of very large birthweights. Between the limits $5.75 \mathrm{lb}$. to $10.25 \mathrm{lb}$. for girls and $6.25 \mathrm{lb}$. to $10.75 \mathrm{lb}$. for boys (a range which includes 88 per cent. of birthweights of normal children) there was no difference between the normal and the backward series.

4. The excess of low birthweights amongst the backward children increases steadily as birthweight falls. The excess is not more than about 50 per cent. in the region $4.75 \mathrm{lb}$. to $5.75 \mathrm{lb}$. for girls and $5 \cdot 25 \mathrm{lb}$. to $6 \cdot 25 \mathrm{lb}$. for boys. But there are about four times as many birthweights below $2.75 \mathrm{lb}$. and $3.25 \mathrm{lb}$. respectively in the backward children as there are amongst the normals. The excess of low birthweights is little greater amongst idiots and imbeciles than it is amongst the feeble-minded and borderline defectives.

5. The fact that special school children and certified defectives form a relatively small proportion of the population means that the figures just quoted indicate that the child of low birthweight is much more likely to be of normal mentality than to be defective or very backward. The chance for those of the lowest birthweights, as quoted above, is probably not worse than 10 per cent.

We are greatly indebted to the Middlesex County Council and the London County Council for the facilities made available at the schools, and in particular we should like to acknowledge the generous assistance of Dr. A. A. Turner, School Medical Officer of the Borough of Finchley, and all the head teachers at the Finchley schools and at the additional special schools for educationally subnormal children situated in the wider areas. The birthweights of the sample of certified mental defectives were very kindly provided by $\mathrm{Dr}$. R. M. Norman, Medical Superintendant of Stoke Park Colony, Bristol, who had obtained them during the course of a much more detailed investigation into the birth histories of the younger patients under his care. We are indebted to Mrs. M. G. Young for preparing the figure.

\section{REFERENCES}

Asher, C. (1946). Brit. med. J., 1, 793.

Bartlett, M. S. (1937). Proc. roy. Soc., A160, 268.

Karn, M. N. (1947). Ann. Eug., Camb., 14, 44.

Martin, W. J. (1931). Ibid., 4, 327.

Roberts, 'J. A. F., Norman, R. M., and Griffiths, R. (1938). Ibid., 8, 178.

Rosanoff, A. J., and Inman-Kane, C. V. (1934). Am. J. of Psychiat., 13, 829. 
68

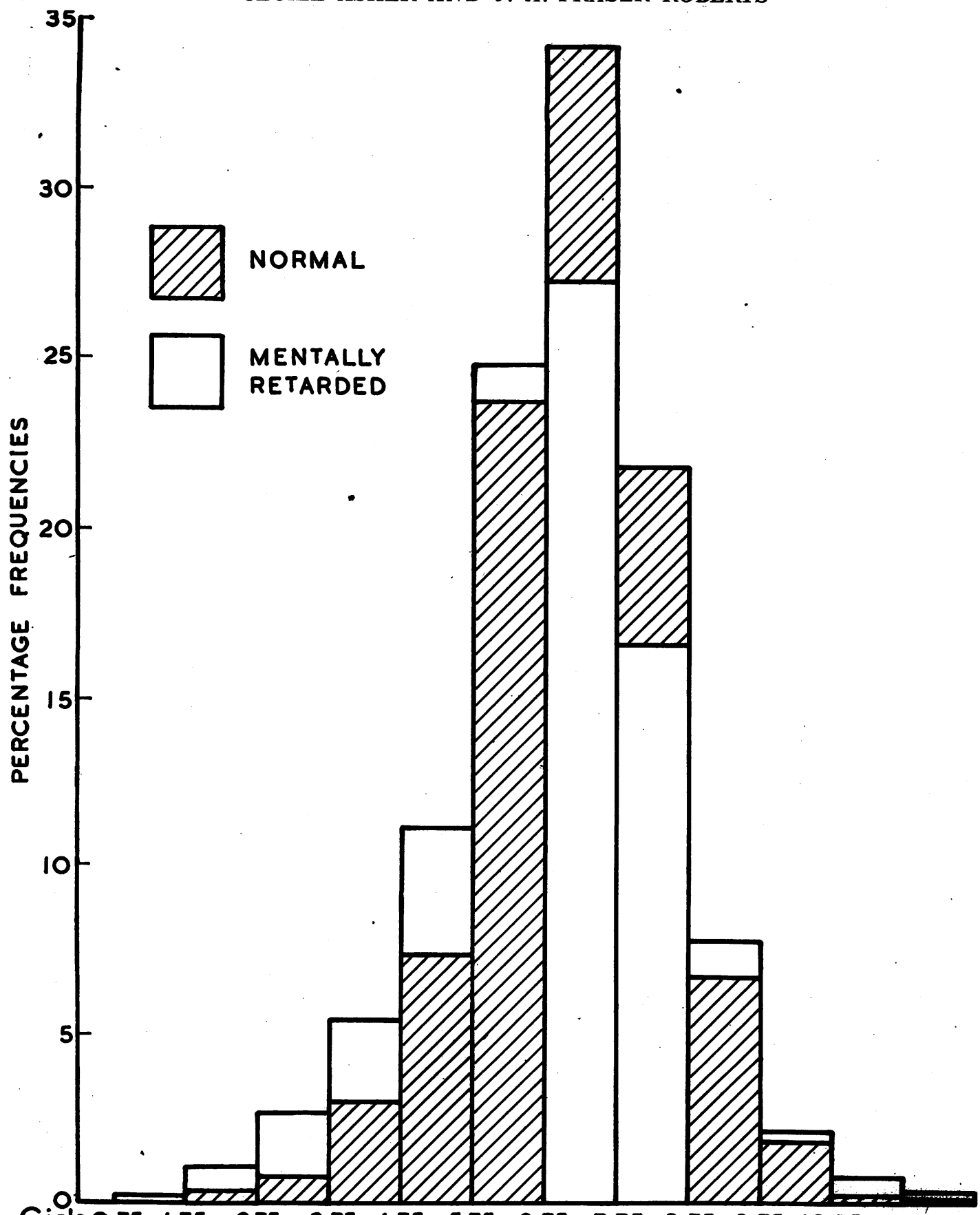

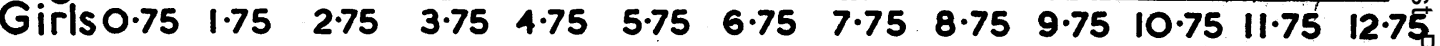
$\begin{array}{llllllllllllllll}\text { Boys } 1.25 & 2.25 & 3.25 & 4.25 & 5.25 & 6.25 & 7.25 & 8.25 & 9.25 & 10.25 & 11.25 & 12.25 & 13.25\end{array}$ GROUP BOUNDARIES Ib.

Fig. 1.-Comparison of percentage frequency distributions of birthweights of 4,800 normal schoolchildren agil 1,220 mentally retarded children (special school and certified deféctives). 